\title{
Historiography as a political battlefield (1956-1989): Italian left-wing historians on early German Social Democracy
}

\author{
Nicola D'Elia* \\ (Received 12 August 2014; final version accepted 5 February 2015)
}

\begin{abstract}
The debate surrounding German Social Democracy during the era of the Second International represents an important chapter in the historiography of post-Second World War Italy. At the same time, it also marks some crucial moments in the political and intellectual life of Republican Italy. This article aims to show the close relationship between the investigation of the past and the ongoing political struggle that has characterised research on this issue. Study of the topic was practically monopolised by left-wing historians, who, in dealing with the history of German Social Democracy, aimed also to direct the political strategy of workers' parties. Considering the studies appearing after the 1956 crisis and in the mid-1970s, such a goal seems evident. It was only during the 1980s that the research opened itself to different perspectives - no longer influenced by ideological controversies.
\end{abstract}

Keywords: Italian historiography; German Social Democracy; Italian Communist Party; Italian Socialist Party

\section{Introduction}

In an article that appeared in Rivista Storica Italiana in 1968, Leo Valiani, an antifascist historian without party affiliation, wrote: 'In the history of German Social Democracy is reflected, in truth, the tragedy of contemporary Germany.' The article reviewed the extensive body of literature, mainly written since the Second World War, which examined the various landmarks of the history of the world's oldest Socialist party. Valiani claimed that the image of the German Social Democratic Party (SPD) in international historiography was directly related as much to its responsibilities for the failure to transform the German Empire into a parliamentary democracy before 1914 - a factor that influenced the outbreak of the First World War - as to the collapse of the Weimar Republic, from which the Second World War had originated (Valiani 1968, 32). Therefore, for many scholars worldwide, the SPD's historical trajectory represented a crucial problem, not just in the history of Germany, but also for the history of Europe as a whole.

For a long time, Italian historiography during the post-Fascist period also dealt extensively with the history of the SPD. As with the majority of international scholarship, it was concerned with the contradictions which marked the existence of the main party of the Second International as a result of adopting a dogmatic Marxist ideology that prevented the SPD from pursuing successful practical politics. However, there are also differences between the Italian approach and that prevailing in other countries: in contrast with the predominant historiographical trend in West Germany, the reformist and revisionist currents within the SPD, which aimed to favour the

*Email: wulfgar2@hotmail.com 
party's integration into the state, were almost completely neglected in Italy. But not even the radical left, which opposed such an integration, was given special attention, as had happened in East Germany. Likewise, Italian historians failed to provide research focusing on the isolation of the SPD in the German Empire, which led the party to organise itself as a 'countersociety' believing in alternative values, according to an historical-sociological approach followed especially by Anglo-Saxon authors. ${ }^{1}$

Moreover, the Italian historiography on the SPD was characterised by two remarkable peculiarities: (1) left-wing historians held a practical monopoly on the study of the matter; and (2) their assessment was broadly affected by the ongoing political struggle in Italy. The first aspect can be explained by taking into account that, as a monograph by Gilda Zazzara (2011) emphasises, the study of contemporary history in post-war Italy took place mainly outside the traditional academic context, due to a widespread prejudice in the universities against the possibility of looking at recent events with scientific objectivity. Thus, it was left-wing parties, and in particular the Communists, that provided the first public spaces (journals, centres for research, publishing houses) in which new historiographical approaches could be developed. Therefore, such political forces became very attractive to those historians who were oriented toward contemporary problems and issues. In such a context, the resumption and innovation of studies of the labour movement, stimulated by important cultural institutions like the Istituto Feltrinelli in Milan and the Fondazione Gramsci in Rome (both founded in the early 1950s), naturally represented the core of left-wing historians' engagement in Republican Italy. As Zazzara points out, 'the action taken in this field was profound and had enduring effects on Italian historiography, leaving its mark on several generations of scholars' $(2011,58)$.

It might seem prosaic to say that Italian left-wing historians connected scientific activity with participation in political struggle. Indeed, as Massimo L. Salvadori $(2003,188)$ noted, the entire historiography of united Italy had been very much characterised by political and ideological bias, as a result of the deep divisions present at all landmarks in the political and social development of the country from unification onwards. However, even if we assume that every historian is influenced by his/her own political viewpoint, this does not automatically imply support or endorsement of a particular party's aim or strategy. What marks historical research on the SPD is that it echoed, for a long time, a series of crucial issues that were debated between the two main leftist parties in Italy (the relationship between democracy and socialism, the labour movement's alliance politics, and the meaning of parliamentarism). It may well be argued that such studies exemplify one of the distinctive features of Italian post-war historiography on contemporary history - what Nicola Gallerano (1987) called the 'politicità' of history, meaning that the study of history was important not only for interpreting the past but also for deciding upon modern-day politics. Indeed, as we will see below, by debating the SPD's history, Italian historians aimed chiefly to support or influence the political strategy of the Italian left. Their dealing with this issue marked some crucial phases in the political and intellectual history of Republican Italy. For this reason, studies of the SPD in the era of the Second International represent an important chapter in the history of Italian culture after the Second World War. Furthermore, they are among the most important achievements of Marxist historiography. It is useful to summarise the various chronological landmarks of the Italian historians' engagement with this topic, before analysing them in detail:

(1) The first historical approach to the SPD occurred between the late 1950s and the early 1960s due to the impulse of Italian Communist Party (PCI) historians like Ernesto Ragionieri and Giuliano Procacci. The crisis that hit the international Communist 
movement in 1956 prompted them to investigate the transnational aspects of the historical development of Socialist organisations. At the same time, they wanted to reaffirm the value both of the Communist tradition and of the PCI's political strategy, which had been under attack by the Italian Socialist Party (PSI). It is not surprising that their assessment of the SPD's historical experience aimed particularly at pointing out its limits. This negative assessment was also meant as a warning to the PSI for choosing to abandon united front politics with the PCI: according to the Communist historians, it would be a mistake to get back on a track that had been historically proven wrong.

(2) A more positive attitude toward the SPD developed in the mid-1970s due to the work of Socialist-oriented scholars - in particular, Massimo L. Salvadori. The PCI's new approach toward 'Eurocommunism' on one hand and the advent, within the PSI, of an increasingly antagonistic line toward the Communists on the other, produced favourable conditions for a new debate on the social democratic tradition that was focused, in particular, on the figure of Karl Kautsky - traditionally regarded as the most influential Marxist theorist of the Second International.

(3) Finally, during the 1980 s, different perspectives were opened up after the change in Italian historiography that marked the end of the hegemony of traditional political history. The new cultural environment supported efforts to investigate the SPD's history from an independent position - one no longer influenced by the ideological clash between Socialists and Communists. The most significant examples of this line of research were the studies by Franco Andreucci. However, such an approach would not take root in Italy, where the matter was inextricably related to political struggles. It is no coincidence that, by the time of the grave crisis that hit the Italian left after 1989, the historiography of socialism and the labour movement entered a phase of irreversible decline.

\section{The Communist historians' approach after 1956}

In Italy, the history of the SPD began to be investigated after the 1956 crisis, which opened a new phase of the PCI's cultural policy. The results of the Twentieth Congress of the Soviet Communist Party (PCUS) and the condemnation of Stalinism, as well as the Soviet repression in Hungary, had considerable repercussions on Marxist intellectuals, particularly Communists. A massive disorientation took place among them, which led a number of them to abandon the PCI. The case of Delio Cantimori, at that time the most prominent Marxist historian in Italy, who decided to leave the party quietly, is particularly well known. The events of 1956 also had a profound impact on the historians who chose to stay in the party, putting into motion a process of rethinking the way in which they had previously dealt with the historical tradition of the Italian labour movement. Marxist historians became aware of a need to investigate the events and issues located at the core of the Socialist movement during the period in which this had become a protagonist in European and even world history; therefore, the new approach insisted on a more serious consideration of the international dimension of socialism (Cortesi 1961b, 244-245). The most significant examples of this trend were Ernesto Ragionieri's (1961a) research on the relationships between the SPD and Italian Socialists, and Giuliano Procacci's (1958) essay on the Second International. Such studies contributed considerably towards innovations in the Italian historiography of the labour movement, overcoming the provincialism by which, until then, it had been permeated (Detti 1981, 276). Ragionieri's work was particularly aimed at highlighting the SPD's influence on the process of the foundation of the PSI. This was an effect 
of the leading role exercised by the German party - as a result of the establishment of Marxism within it, its solid organisation, its brilliant electoral victories and the prestige of its leaders - on the whole international labour movement in the period after the Franco-Prussian War. ${ }^{2}$

The meaning of the intense historical reflection that arose in Italy between the late 1950s and the early 1960s on the SPD (see also Ragionieri 1957, 1958, 1961b; Procacci 1959, 1960) lay not just in the different perspective from which the origins of the Italian labour movement began to be investigated, but also in its close connection with contemporary political issues. In particular, such a reflection must be examined in the context of the consequences of the 1956 events on the relationships between the two main leftist Italian parties. One of the best-known responses to these events was the decision of the PSI to dissolve the united action agreement with the PCI. Consequently, Italian Socialists were more inclined to blame the 1921 Livorno split as a pointless mistake. This position was closely linked to their purpose for reunifying with the Italian Social Democratic Party, in order to promote the creation of a 'third force' between Communists and Catholics.

Facing such pressure by the PSI, the Italian Communist leader, Palmiro Togliatti, and the party's leading group were urged to demonstrate the historical necessity of the PCI's birth, which represented a decisive step forward in the development of the Italian labour movement. Given the disorientation within the party, it should be strongly claimed that the Livorno split had been the right thing. In other words, the Communists felt the need to reaffirm the legitimacy of the role played by the strongest leftist party in Italian history: it had been an active protagonist in the fall of Fascism and, in the post-war period, had become the core of a dynamic group of political and social forces, which provided an alternative to the conservative bloc led by the Christian Democrats. This was the result of an effective political strategy, which was identified with the formula of 'progressive democracy'. Following this plan, the PCI had become a major revolutionary force, well established in the national fabric (on these topics, see, above all, Masella 1979; Scotti 2011). ${ }^{3}$

In such a context, Communist historians were concerned with questioning the PSI's connection with the democratic tradition of the Risorgimento, with which they believed only the PCI was justified to claim continuity. ${ }^{4}$ By emphasising the crucial role played by the SPD in the birth of the PSI, Ragionieri aimed to counter different interpretations, such as that of Luigi Cortesi (1961a), which insisted rather on the idea of the PSI's autochthonous origins and of its roots in the Risorgimental left tradition. Ragionieri's (1961a, 36) assertion - that 'the assimilation of the first elements of Marxism by the Italian labour movement occurred through the influence of the example of German Social Democracy' - was closely associated with the criticism of the cultural and political limits of the PSI's early leading group located in Lombardy and, in particular, of Filippo Turati. ${ }^{5}$

At the same time, Italian Communist-oriented historiography blamed the social democratic tradition as a whole, whose failure appeared most explicitly in recent historical developments in Germany. Indeed, the SPD had been unable to oppose the Nazi rise to power and, in the new political phase which had opened after the Second World War, had been revealed as lacking the capacity to constitute an efficient alternative to the conservative forces that were increasingly dominant in Adenauer's Germany. ${ }^{6}$ This strengthened the view that the SPD's historical development was 'the central chapter of the history of contemporary Germany' (Procacci 1959, x) and stimulated a retrospective reflection, aimed at searching for the roots of the crisis. The reflection by Communist historians focused on explaining the collapse of the Second International just after the outbreak of the First World War. According to Procacci, the importance of studying the events which had led international socialism to its defeat on 4 August 1914 - the 
day on which the SPD parliamentary group had voted for war credits - lay in the sense of their 'contemporaneity' and in the conviction that 'too many are the problems of our time whose solution or even just formulation presupposes a judgement of that period' (Procacci 1958, 105).

Communist scholars suggested that the origins of the SPD's historical failure should be searched for in the years of its rise, when it had become a model for all other Socialist parties that were then developing in Europe and across the world. ${ }^{7}$ As Procacci argued, agreeing with the thesis of the American historian Rudolf Schlesinger (1953), the main limitation of the SPD had been its inability to 'develop a politics that could represent an alternative to that of the Prussian state, by gathering around the working class all the forces interested in the fulfilment of the democratic revolution' (Procacci 1958, 145). Therefore, the SPD had failed to recognise the importance of the relationship between democracy and socialism, as it had restricted its own political action to the mere defence of the working class's immediate interests. Such limits, added Ragionieri, were evident in the Erfurt programme of 1891, which had marked the definitive victory of the Marxist orientation within the party. In this programme, in fact, there was no reference to the purpose of achieving a democratic republic in Germany as a necessary step on the way toward socialism. This was a question, as Ragionieri (1961a, 309) pointed out, 'that, from the Bernstein-Debatte to the revolution of November 1918 and onwards, would reveal itself as crucial to the fate of the German labour movement'.

The assessment of the SPD by Italian Communist historians reflected views that had been very popular among German Communist-oriented intellectuals of the interwar years. They found their most complete exposition in the works of Arthur Rosenberg (1928, 1938). According to Rosenberg's interpretation, the SPD and, more generally, the Socialist parties of the Second International, had deviated from Marx and Engels' views of revolutionary strategy, founded on the idea of an alliance between the working class and other progressive forces, united in a democratic movement to overthrow the reactionary ruling classes. The SPD leadership, convinced that the final victory of socialism depended, above all, on the working class's strength and organisation, had developed a political attitude aimed mainly at improving the economic condition of the industrial workers. In this way, a corporatist view had been established in the party, which pushed it into isolation and rendered it unable to intervene successfully in crucial political issues.

To whom and what should the limits of the SPD's political strategy be attributed? Intellectuals like Rosenberg and, especially, Karl Korsch $(1923,1929)$ argued that they were the result of a fatalistic and deterministic view of Marxism developed by Karl Kautsky. Korsch claimed that Kautsky was responsible for turning Marx and Engels' thought into a party ideology that pivoted on the ineluctability of revolution. The question of the relationship between the evolutionary, fatalistic conception of Kautsky's Marxism and the attitude of passive expectation of socialism's victory, which was typical of the Second International's parties, was revived in the 1950s by Erich Matthias (1957) in a well-known study extensively influenced by Korsch's judgement.

Italian Communist historians' interpretation of Kautsky's role in the SPD is broadly indebted to the works of Rosenberg, Korsch and Matthias. Kautsky reflected better than any other, as Procacci $(1959, \mathrm{x})$ pointed out, 'the course of that complex and contradictory historical process led the strongest Socialist party of the Second International from big victories at the turn of the century to the August $4^{\text {th }}$ defeat'. Kautsky was charged with distancing Marxism from the revolutionary tradition of 1848 , because of an unyielding view of historical development as much as a conception of class struggle based on a strict contrast between the working class and other social groups. Such a deficiency, according to Procacci, had appeared most explicitly in Kautsky's outlook on the agrarian question, which attributed little importance to the peasantry as 
a driving force for revolution. For Italian Communist historians, the idea of democratic revolution as a necessary precondition for Socialist revolution substantially differentiated Marx and Engels' political positions from Kautsky's. Ragionieri (1958, xx) also blamed Kautsky for a view of Marxism that 'presented the inevitability of the victory of socialism' rather than showing 'the ways of achieving it'. Moreover, he argued that there was 'a very close connection' between Kautsky's interpretation of Marxism and 'the conception of history and social development' that inspired the SPD’s Erfurt programme (Ragionieri 1961a, 159).

Therefore, it was a rather disapproving judgement which, in the late 1950s and the early 1960s, circulated among Italian historians regarding the SPD in the era of the Second International. So, Cantimori was wrong when he wrote to Gastone Manacorda, in a letter during the spring of 1957, that he was concerned that Procacci's and Ragionieri's forthcoming studies represented a concession to revisionism (Cantimori and Manacorda 2013, 329-331). ${ }^{8}$ On the contrary, they followed the Communist tradition breaking with the schemes of dogmatic Marxism which had developed within the SPD and the Second International due to Kautsky. Moreover, their approach was in line with the political orientation of the party's leading group. It is no coincidence that the SPD's strategy was criticised by Communist historians precisely for having failed to achieve the goal which the Togliattian conception of "progressive democracy' considered crucially important in paving the way to socialism: to build an alliance of political and social forces committed to the development of an advanced democracy.

In this case, it is quite clear that historical investigation was affected by the urge to support a political cause. It is also worth noting that, although the reflection on the SPD by Italian Communist historians took place almost exclusively in an academic context (books and articles in scientific journals), its results were echoed in magazines aiming to support the PCI's cultural policy. Particularly interesting, in this respect, is the review of Ragionieri's research on the relationships between the SPD and Italian Socialists written by Procacci for Rinascita - the monthly journal edited by Togliatti himself. Here, Procacci was first concerned to reinforce the belief that Marxism and the SPD 'were not the same thing'. Moreover, he emphasised the different approaches of Turati and Labriola towards the leading party of the Second International: the latter, by focusing 'on the issue of the relationship between Socialist and bourgeois-democratic revolution', had come to a more critical and effective view of the SPD's character (Rinascita, September 1961, 728-729). It is well known that Italian Communists regarded Labriola's Marxism, on account of its peculiarities in relation to the deterministic and evolutionary trend prevailing within the Second International, as a cornerstone of their own political tradition. Therefore, by claiming the superiority of Labriola's view over that of Turati, founder of the Italian Socialist Party, Communist historians were not only advancing a historical analysis, but also participating in the political polemics which, after the 1956 crisis, placed their party in opposition to the PSI.

\section{Salvadori's book on Kautsky, and its critics}

The interpretation established by Communist historiography in the period after 1956 was barely questioned for many years, and it prevailed until the middle of the 1970s (Ragionieri 1968; Paggi 1974). Before then, only Valiani $(1968,32)$ dared to argue that 'the most definitely democratic force, often the only democratic force, in Germany has been Social Democracy', although his judgement on the SPD's approval of war credits on 4 August 1914 was nevertheless negative. ${ }^{9}$ However, interpretations began to change in the second half of the 1970s, when a more positive evaluation of Kautsky developed. 
This was primarily due to the publication in 1976 of Massimo L. Salvadori's Kautsky e la rivoluzione socialista 1880-1938, which represents the broadest study so far on Kautsky's political thought by an Italian scholar. ${ }^{10}$ This work appeared in a political context marked by the PCI's strong electoral advance and the rise, within the Socialist field, of more convinced autonomous positions aiming to pull the PSI out of its state of ideological subalternity to the largest party of the left. Salvadori's book was part of the cultural struggle, launched at that time by the Socialist journal Mondoperaio, against the traditional benchmarks of Communist ideology. In this respect, it is enough to mention Norberto Bobbio's articles, in which the philosopher of Turin asked Italian Communists to assert clearly what their own conception of democracy was. According to Bobbio and other Socialist-oriented intellectuals, among them Salvadori himself, the full acceptance by the PCI of the principles of Western liberal democracy, able to guarantee pluralism and respect for civil and political liberties, was incompatible with its devotion not only to Leninism but also to Gramsci's views on hegemony, which were assumed to have nothing to do with any idea of democratic socialism (on this topic, see Gervasoni 2013, $31-40)^{11}$

It was in such a context that the re-evaluation of Kautsky's role took place. In particular, Salvadori $(1979,18)$ gave Kautsky credit for clearly forecasting a series of problems which, just at that time, had become a matter of controversy among the left-wing parties in Italy, namely 'the relationship between democracy and socialism, between the state and the worker's movement, between capitalism and the role of the proletariat as a class'. In this respect, Salvadori emphasised Kautsky's conception of parliamentarism and political democracy, which departed from the idea of doing without the representative institutions bequeathed by liberalism in the transition to socialism. Indeed, Kautsky was aware that 'the complex problems posed to the worker's movement by the social evolution of the developed capitalist countries' would make the maintenance of the parliamentary system indispensable (Salvadori 1979, 12). Salvadori's appreciation of Kautsky's political views occurred in conjunction with a new approach, which, in the meantime, developed into the Communist parties of Western Europe, the so-called 'Eurocommunism'. It represented a departure from Lenin's revolutionary strategy, which aimed for the fulfilment of the dictatorship of the proletariat, and, in the eyes of Salvadori $(1979,13)$, an approximation to positions that could 'be defined ... as essentially "Kautskyist"'. Significantly, Salvadori's work dealt extensively with the themes that had been at the core of Kautsky's polemics against the Bolsheviks after the October Revolution, and emphasised that Kautsky's outlook on the state and democracy was opposed to Leninism. Salvadori $(1979,12)$ argued that by the last decade of the nineteenth century, when Kautsky was an undisputed authority in the Second International, he already held a political conception 'that would inevitably clash with Soviet theory and the practise of the government of the Bolsheviks'.

It is evident that Salvadori's approach to Kautsky was quite different from that of Communist historians after 1956. Unlike them, Salvadori gave Kautsky credit for recognising the importance of the relationship between democracy and socialism. In this respect, it must be noted, however, that Salvadori simply pointed out that Kautsky had assigned a pivotal role to parliament and representative institutions in the process of transition toward socialism. On the other hand, Salvadori neglected to focus on Kautsky's strategy for achieving democracy in Wilhelmine Germany: in particular, he declined to discuss, in depth, the crucial issue of whether the most influential ideologist of the Second International had really been averse to an alliance between the working class and other progressive forces. On these points, Salvadori's analysis was lacking and did not provide an effective response to the critical assessment carried out by Communist historiography. His main concern was to emphasise the actuality of Kautsky, as he 
did in an interview given to Mondoperaio (January 1977, 108-110). Such an approach was also confirmed in other writings in which Salvadori spoke more as a public intellectual than as a historian. He aimed, as already mentioned, to show the similarities between the view held by the social democratic tradition represented by Kautsky and the political strategy adopted by the PCI after its recent turn toward 'Eurocommunism' (Salvadori 1978, xv-xix).

Salvadori's book had an important impact on the political debate, but was received rather critically. Communist-oriented scholars disapproved of the thesis that Kautsky's conception of democracy was valuable as the 'landing place' in the development of Western European Communist parties. In this respect, the position taken by Giuseppe Vacca is remarkable. He regarded as unfounded the idea that the ongoing reassessment within the PCI concerning the direct democracy of Sovietism, questioning whether it represented the political form of the transition period to socialism, would be orientated toward 'the recovery of Kautsky's reflections on parliamentarism' (Vacca 1977, 295). Instead, as Vacca pointed out, such a reassessment was the result of a long consideration that had taken place within the Italian Communist tradition from the late 1920s, with the intention of finding different solutions from those attempted in the Soviet Union. The outcome had been the development of a 'new kind of democracy' - the socalled 'progressive democracy' - on which the PCI's original experience in the 30-year period after the Second World War was based. 'We are above and beyond Kautsky as we are above and beyond the historical and theoretical horizon, to which not only Kautsky but essentially "Leninism" itself belongs', Vacca $(1977,296)$ argued, thus rejecting any possibility of recovering the social democratic tradition.

Another response by the PCI to the challenge launched by Salvadori was the 1980 publication, by the party's publishing house, of the large monograph on Kautsky written by the Polish scholar Marek Waldenberg. In the introduction to the Italian edition, the author openly disputed Salvadori's interpretation, emphasising the fluctuations of Kautsky's thought concerning the value of democracy and parliamentarism (Waldenberg 1980).

If Salvadori's essay did not receive positive feedback within the Communist field, it was also criticised by intellectuals who drove the parties of the Italian left to embrace a decidedly reformist outlook. For example, Domenico Settembrini (1978, 154-155), besides considering the cultural level of the book as 'flat', complained that it was also wrong as 'a political operation', trying to move Italian Communists toward liberal socialism. Indeed, he remarked that 'Kautsky will remain convinced to the end - and Salvadori admits this - that democracy and parliament are good, but the fundamental goal has to remain complete collectivisation' (Settembrini 1978, 155). Settembrini did appreciate those aspects of Kautsky's thought which marked a dividing line with Leninism: namely, his hostility to the idea of imposing socialism by despotic means and his inflexibility on the need for liberal democratic institutions, considered as an undeniable requirement for the exercise of political power by the proletariat. However, he was mainly concerned with emphasising, in view of the subsequent experiences of Western socialism, the negative consequences of Kautsky's position. According to Settembrini (1974, 222), Kautsky's main historical responsibility had been to oppose a reformist development of the labour movement in order to preserve the expectation of revolution, delaying its integration into the structures of a liberal democratic society for decades.

Comparing these works with the studies issued after the 1956 crisis, it is clear that they have more than a little in common: (1) all of them were stimulated essentially by political concerns; and (2) no matter what the political views of the historians, they all identified social democratic traditions with Kautsky's position. There was, however, a remarkable difference in the evaluation of Kautsky's betrayal of revolutionary Marxism: both Settembrini and Salvadori, 
distancing themselves from the assessment expressed by Communist historiography, emphasised that his theoretical and political conceptions could not be considered responsible for the SPD's integration into German society, which was instead the product of objective historical conditions not favourable for revolution (Settembrini 1974, 153-154, 1978, 125; Salvadori 1979, 18-19).

\section{New perspectives beyond ideological disputes}

From the second half of the 1970s onwards, however, the attention of Italian historiography to the history of international socialism diminished significantly, as a result of the change that brought about the loss of the supremacy of political history and the rise of social history. This change, carefully analysed by Nicola Gallerano (1987), mainly affected Marxist historiography, and was closely related to the disappearance of its hegemonic role as well as to the crisis of the political plan based on Marxism. Nonetheless, further studies on the SPD appeared in the new environment, which opened different perspectives from past research. Such studies, however, were also the work of left-wing historians.

Here, the research of Franco Andreucci - a disciple of Ragionieri, and for a long time affiliated with the PCI - stands out in particular, especially for its attempt to separate the investigation of the SPD's history from ideological controversies. Andreucci was influenced by the important and innovative book Sozialismus und deutsche Sozialdemokratie, written by HansJoseph Steinberg in 1967, which demonstrated that the SPD's ideology was the result of various components. ${ }^{12}$ He emphasised the necessity of going beyond the interpretation of Marxism in the epoch of the Second International as a uniform ideological orientation due to the impoverishment of Marx's thought. This meant rejecting the polemical categorisation of 'Kautskyianism', which had deeply influenced the approach to this topic from the Second World War onwards. According to Andreucci, previous evaluations of the period of the Second International needed to be reconsidered, since its historical relevance as the point of encounter between Marxism and the worker's movement was undeniable. It had been during that period that Marxist ideas saw a wide geographic expansion and became the belief of millions around the world. In this circulation process, the propelling role played by the SPD, by means of its press and the works of its theorists - principally Kautsky - had been crucial. As Andreucci (1979a, 17) pointed out, 'the period of the greatest growth of German Social Democracy's influence' had been the last decade of the nineteenth century: all Socialist parties that arose at that time 'referred explicitly to the structure, program and doctrine of the SPD'.

Andreucci, in his book of the late 1980s titled Socialdemocrazia e imperialismo, showed most clearly that the SPD's political culture was far from being characterised by a homogeneity of positions under the cloak of party ideology. He highlighted that, at least from the end of the nineteenth century, the debate on imperialism had caused a real political contrast within the party and stimulated the development of divergent positions, which would clash with each other. This work, which updated previous research from the 1970s (see in particular Andreucci 1971, $1974,1979 b)$, is still the only study by an Italian author that offers a broad picture of the discussions within the SPD over the years of the Second International. It also does not limit its analysis to the best known sources or to the positions of the main protagonists. A subject like imperialism, as Andreucci $(1988,9)$ remarked, 'is not only of a theoretical nature, but is rooted in political discussion'. Therefore, the investigation required consideration not only of the views of party leaders, but also of rank-and-file members, moving from a traditional political history towards a history of mentality focused on the so-called marxismo collettivo. At the same time, 
Andreucci blamed 'the influence that Leninism and dogmatic Marxism had and continue to have' on the historiography dealing with the history of the SPD and, in particular, with the matter of imperialism, which suffered from 'the weight of political struggles' (1988, 8-9).

Andreucci's book diverged in several respects from previous Italian studies. First, the core of the discourse was no longer the issues of the relationship between democracy and socialism or of the labour movement's alliance politics, but instead the views on foreign politics developed within the SPD from the late nineteenth century to the eve of the First World War. Second, it offered a different explanation for the crisis and failure of the most important Socialist party of the Second International: its main flaw, according to the author, was to give too little consideration to 'the role of national movements of oppressed peoples' due to the continuation, among German Marxists, of Engels' old view that the necessary driving force for revolution was, in any case, 'the working class of the capitalist West' (Andreucci 1988, 17).

This new line of research, developed over the 1980s, stands out as innovative in other respects as well. Kautsky's intellectual profile, for example, was reconsidered from a different viewpoint that focused on 'the social history of ideas', as in the case of the monograph by Andrea Panaccione titled Kautsky e l'ideologia socialista. It represents an attempt to reconstruct, through Kautsky's prism, the various elements of the ideology that came together under the title of Marxism in the final decades of the nineteenth century, destined to influence the 'thoughts, actions and expectations of a multitude of people' (Panaccione 1987, 10).

However, this renewed approach to the history of the SPD had little time to develop. Indeed, the world-changing events surrounding the fall of the Berlin Wall and their momentous repercussions on Italian politics - first the PCI's transformation into the Partito Democratico della Sinistra, and then the PSI's collapse due to Tangentopoli - dealt a heavy blow to studies on socialism and the labour movement, which had been linked for far too long with the political concerns of Italian leftist parties. Nowadays, the SPD's history has practically vanished from the landscape of Italian studies; but there is also another, more serious, danger on the horizon: the repression of historical memory of the historiographical debate on this issue, which was a significant part of the cultural life of post-war Italy.

\section{Acknowledgements}

This article is the revised and extended version of a paper presented at the workshop in honour of Prof. Franco Andreucci entitled 'Culture politiche e partiti nell'Europa contemporanea', held at the University of Pisa on 14 February 2014.

\section{Disclosure statement}

No potential conflict of interest was reported by the author.

\section{Notes}

1. For an overview of the international literature on the SPD's history, see Valiani (1968) and Salvadori (1981).

2. The importance of Ragionieri's work was emphasised by Georges Haupt $(1978,185)$, who pointed out how it 'left glimpse, on the example of Italy, that the international influence of German Social Democracy before 1914 represents a wider and more problematic research field'.

3. Moreover, on the impact of the events of 1956 on the Italian left parties cf. Flores and Gallerano (1987, 15-39); Ilardi (1987, 40-49) and Sabbatucci (1987, 50-65). Togliatti's view of 'progressive democracy' is extensively analysed in Vacca (1974). For its specific meaning in the PCI's political strategy after 1956, see Sassoon $(1981,120-139)$. 
4. By considering itself the true heir of the progressive traditions of the Risorgimento, the PCI aimed to achieve cultural hegemony in post-war Italy. On this crucial aspect of the Italian Communists' strategy, see the stimulating account by Carpi (2011).

5. Ragionieri's conclusions were contested by Cortesi, who asserted that the Marxist development of the Socialist group in Milan was only partly the result of the SPD's influence. According to him, it was a process that happened, to a greater extent, independently, stimulated mainly by the advanced level of the objective conditions of class struggles and the cultural environment that characterised the Lombardy contest (Cortesi 1961b, 249-251).

6. See the issue of the journal Nuovi Argomenti with the title 'Appunti sulla destra tedesca', published in 1960/1961, that dwelt on this topic. It contains also a contribution by Ragionieri, in which he blamed the German Social Democrats for having 'long resigned the problem of the German State to the ruling classes' hands' (Ragionieri 1960/1961, 244).

7. In this regard, the Italian approach was quite different from the one then prevalent in the international historiography, which aimed, rather, to investigate the period of the SPD's crisis. For two examples of such a trend, see Schlesinger (1953) and Schorske (1955).

8. In this regard, it is worth noting that Cantimori's decision to leave the PCI was not due to a revision of his belief in Communist ideology. It was based primarily on his refusal to approve the idea that the scholar's intellectual engagement should be subordinated to the needs of the political struggle (on this point, see the comments by Vivarelli 2014, 140-144).

9. He regarded such a decision as a mistake, as it led later to a split within the party and, therefore, the German labour movement stood divided and weakened when, after the military defeat of autumn 1918 and the collapse of imperial government, it was in charge of the new republican regime (Valiani 1968, 58).

10. The work is also available in English and German (see Salvadori 1979, 1982).

11. In this respect, it is also worth mentioning Il marxismo e lo Stato (1976), Egemonia e democrazia (1977) and Muti (1977). On the intellectual engagement of Mondoperaio in the second half of the 1970s, cf. Fedele (2012). In general, on the challenge launched by the PSI against the PCI from the mid-1970s, cf. Amato and Cafagna (1982).

12. It was Andreucci himself who made sure that this work was available in Italian as well (see Steinberg 1979).

\section{Notes on contributor}

Nicola D'Elia is an independent scholar. His main fields of research are the history of socialism and the labour movement between the end of the nineteenth century and the First World War, and the history of German-Italian cultural relations in the interwar period. He has published the books Democrazia e 'modello inglese': Eduard Bernstein scrittore politico nell'esilio di Londra (1890-1901) (Florence 2005), and Delio Cantimori e la cultura politica tedesca (1927-1940) (Rome 2007).

\section{References}

Amato, G., and L. Cafagna. 1982. Duello a sinistra: Socialisti e comunisti nei lunghi anni '70. Bologna: Il Mulino.

Andreucci, F. 1971. "Engels, la questione coloniale e la rivoluzione in Occidente." Studi Storici 12: 437-479.

Andreucci, F. 1974. "La socialdemocrazia tedesca e l'imperialismo alla fine del XIX secolo." Studi Storici 15: $325-363$.

Andreucci, F. 1979a. "La diffusione e la volgarizzazione del marxismo." In Il marxismo nell'età della Seconda Internazionale, vol. 2 of Storia del marxismo, 6-58. Turin: Einaudi, 1978-1982.

Andreucci, F. 1979b. "La questione coloniale e l'imperialismo." In Il marxismo nell'età della Seconda Internazionale, vol. 2 of Storia del marxismo, 868-893. Turin: Einaudi, 1978-1982.

Andreucci, F. 1988. Socialdemocrazia e imperialismo: I marxisti tedeschi e la politica mondiale $1884-$ 1914. Rome: Editori Riuniti.

Cantimori, D., and G. Manacorda. 2013. Amici per la storia: Lettere 1942-1966, edited by A. Vittoria. Rome: Carocci. 
Carpi, U. 2011. "Il Partito Comunista Italiano e De Sanctis negli anni Cinquanta: Classe operaia ed egemonia nazionale." Quaderns d'Italià 16: 67-84.

Cortesi, L. 1961a. La costituzione del Partito Socialista Italiano. Milan: Avanti!.

Cortesi, L. 1961b. "A proposito dei rapporti tra socialdemocrazia tedesca e socialismo italiano." Rivista storica del socialismo 4: 243-264.

Detti, T. 1981. "Storia politica e storia sociale nella storiografia sul movimento operaio." In L'Italia unita: Problemi ed interpretazioni storiografiche, edited by R. Rainero, 271-286. Milan: Marzorati.

Egemonia e democrazia: Gramsci e la questione comunista nel dibattito di Mondoperaio. 1977. Foreword by F. Cohen. Rome: Quaderni di Mondoperaio.

Fedele, S. 2012. Primavera socialista: Il laboratorio "Mondoperaio" 1976-1980. Milan: Franco Angeli.

Flores, M., and N. Gallerano. 1987. "La politica." In Il '56 e la sinistra italiana: Un'occasione mancata?, 15-39. Milan: Franco Angeli.

Gallerano, N. 1987. "Fine del caso italiano? La storia politica tra 'politicità' e 'scienza'." Movimento operaio e socialista 10: 5-25.

Gervasoni, M. 2013. La guerra delle sinistre: Socialisti e comunisti dal 68' a Tangentopoli. Venice: Marsilio.

Haupt, G. 1978. "Un partito guida: L'influenza della socialdemocrazia tedesca nel Sudest europeo." In G. Haupt, L'Internazionale socialista dalla Comune a Lenin 185-233. Turin: Einaudi.

Ilardi, M. 1987. "Il Partito Comunista Italiano." In Il '56 e la sinistra italiana: Un'occasione mancata?, 40-49. Milan: Franco Angeli.

Korsch, K. 1923. "Marxismus und Philophie." Archiv für die Geschichte des Sozialismus und der Arbeiterbewegung 11: 52-121.

Korsch, K. 1929. Die materialistische Geschichtsauffassung: Eine Auseinandersetzung mit Karl Kautsky. Leipzig: C.L. Hirschfeld.

Il marxismo e lo Stato: Il dibattito aperto nella sinistra italiana sulle tesi di Norberto Bobbio. 1976. Foreword by F. Cohen. Rome: Quaderni di Mondoperaio.

Masella, L. 1979. Passato e presente nel dibattito storiografico: Storici marxisti e mutamenti della società italiana 1955-1970: Antologia critica. Bari: De Donato.

Matthias, E. 1957. "Kautsky und der Kautskyanismus. Die Funktion der Ideologie in der deutschen Sozialdemokratie vor dem Ersten Weltkriege." Marxismusstudien 2: 151-197.

Muti, C., ed. 1977. Egemonia e pluralismo: Il dibattito sul rapporto fra socialismo e democrazia. Venice: Marsilio.

Paggi, L. 1974. "Intellettuali, teoria e partito nel marxismo della Seconda Internazionale: Aspetti e problemi." In M. Adler, Il socialismo e gli intellettuali. In Appendix: "L'intelligenza e la Socialdemocrazia" by K. Kautsky, edited and with an Introduction by L. Paggi. Bari: De Donato.

Panaccione, A. 1987. Kautsky e l'ideologia socialista. Milan: Franco Angeli.

Procacci, G. 1958. "Studi sulla II Internazionale e sulla Socialdemocrazia tedesca." Annali dell'Istituto Giangiacomo Feltrinelli 1: 105-146.

Procacci, G. 1959. “Introduzione.” In K. Kautsky, La questione agraria. Milan: Feltrinelli.

Procacci, G. 1960. "Antonio Labriola e la revisione del marxismo attraverso l'epistolario con Bernstein e con Kautsky (1895-1904).” Annali dell'Istituto Giangiacomo Feltrinelli 3: 264-284.

Ragionieri, E. 1957. "Prefazione." In F. Mehring, Storia della Germania moderna. Milan: Feltrinelli.

Ragionieri, E. 1958. "Prefazione.” In K. Kautsky, Etica e concezione materialistica della storia. Milan: Feltrinelli.

Ragionieri, E. 1960/1961. "Dati sui nazisti nella Repubblica Federale e considerazioni sulla continuità dell'apparato statale dell'imperialismo tedesco." In Nuovi Argomenti 47-48: 214-244.

Ragionieri, E. 1961a. Socialdemocrazia tedesca e socialisti italiani 1875-1895: L'influenza della socialdemocrazia tedesca sulla formazione del Partito Socialista Italiano. Milan: Feltrinelli.

Ragionieri, E. 1961b. "Prefazione.” In F. Mehring, Storia della socialdemocrazia tedesca. Rome: Editori Riuniti.

Ragionieri, E. 1968. Il marxismo e l'Internazionale: Studi di storia del marxismo. Rome: Editori Riuniti. 
Rosenberg, A. 1928. Die Entstehung der deutschen Republik 1871-1918. Berlin: Rowohlt.

Rosenberg, A. 1938. Demokratie und Sozialismus: Zur politischen Geschichte der letzten 150 Jahre. Amsterdam: Allert de Lange.

Sabbatucci, G. 1987. "Il Partito Socialista Italiano." In Il '56 e la sinistra italiana: Un'occasione mancata?, 50-65. Milan: Franco Angeli.

Salvadori, M. L. 1976. Kautsky e la rivoluzione socialista 1880-1938. Milan: Feltrinelli.

Salvadori, M. L. 1978. Eurocomunismo e socialismo sovietico: Problemi attuali del Pci e del movimento operaio. Turin: Einaudi.

Salvadori, M. L. 1979. Karl Kautsky and the Socialist Revolution 1880-1938, Translated by J. Rothschild. London: NLB.

Salvadori, M. L. 1981. "La socialdemocrazia tedesca dalla fondazione all'avvento del nazismo: Una rassegna storiografica.” In M. L. Salvadori, Dopo Marx: Saggi su socialdemocrazia e comunismo 159-216. Turin: Einaudi.

Salvadori, M. L. 1982. Sozialismus und Demokratie: Karl Kautsky 1880-1938. Stuttgart: Klett-Cotta.

Salvadori, M. L. 2003. "Legittimazione politica e storiografia italiana." In Due nazioni: Legittimazione e delegittimazione nella storia dell'Italia contemporanea, edited by L. Di Nucci and E. Galli Della Loggia, 187-225. Bologna: Il Mulino.

Sassoon, D. 1981. The Strategy of the Italian Communist Party: From the Resistance to Historic Compromise, Foreword by E.J. Hobsbawm. London: Frances Pinter.

Schlesinger, R. 1953. Central European Democracy and its Backgrounds: Economic and Political Group Organisation. London: Routledge \& Kegan Paul.

Schorske, C. E. 1955. German Social Democracy, 1905-1917: The Development of the Great Schism. Cambridge, MA: Harvard University Press.

Scotti, M. 2011. Da sinistra: Intellettuali, Partito socialista italiano e organizzazione della cultura (1953-1960). Rome: Ediesse.

Settembrini, D. 1974. "Karl Kautsky e le basi teoriche della socialdemocrazia." In D. Settembrini, Socialismo e rivoluzione dopo Marx 147-279. Naples: Guida.

Settembrini, D. 1978. Marxismo e compromesso storico, edited by F. Orlando. Florence: Vallecchi.

Steinberg, H. -J. 1979. Il socialismo tedesco da Bebel a Kautsky. Rome: Editori Riuniti.

Vacca, G. 1974. Saggio su Togliatti e la tradizione comunista. Bari: De Donato.

Vacca, G. 1977. "Kautsky e noi." In G. Vacca, Quale democrazia: Problemi della democrazia di transizione 291-299. Bari: De Donato.

Valiani, L. 1968. "La storia della socialdemocrazia tedesca (1863-1914)." Rivista Storica Italiana 80: $32-60$.

Vivarelli, R. 2014. "Intorno al carteggio Cantimori-Manacorda.” Archivio Storico Italiano 172: 133-151.

Waldenberg, M. 1980. Il papa rosso: Karl Kautsky. Rome: Editori Riuniti.

Zazzara, G. 2011. La storia a sinistra: Ricerca e impegno politico dopo il fascismo. Rome: Laterza. 